\title{
Nitrogen Fertilization in the Initial Growth of Khaya senegalensis A. Juss Plants Under Greenhouse Conditions
}

\author{
Matheus da Silva Araújo ${ }^{1}$, José Eduardo Dias Calixto Júnior ${ }^{2}$, Vitor Corrêa de Mattos Barretto ${ }^{3}$, Adilson Pelá ${ }^{4}$, \\ Rodrigo Tenório de Vasconcelos ${ }^{5} \&$ Ednaldo Cândido Rocha ${ }^{4}$ \\ ${ }^{1}$ Department of Soil Science, University of São Paulo, Piracicaba, SP, Brazil \\ ${ }^{2}$ University of Brasília, Brasília, DF, Brazil \\ ${ }^{3}$ State University of Paulista, Dracena, SP, Brazil \\ ${ }^{4}$ State University of Goiás, Ipameri, GO, Brazil \\ ${ }^{5}$ Vasconcelos Florestal, Monte Alto, SP, Brazil \\ Correspondence: Matheus da Silva Araújo, Department of Soil Science, University of São Paulo (ESALQ-USP), \\ Piracicaba, SP, Brazil. Tel: 55-64-996-097-330. E-mail: araujomatheus@usp.br
}

Received: June 15, 2019

doi:10.5539/jas.v11n17p235
Accepted: July 30, 2019 Online Published: October 15, 2019

URL: https://doi.org/10.5539/jas.v11n17p235

\begin{abstract}
African mahogany is an exotic specie and its cultivation has increased in Brazil due to the high value of its timber on the international market. Nutrition with nitrogen is an important factor for species with high biomass production and specific studies on this species are essential. The present study aimed to assess the initial growth of African mahogany plants submitted to nitrogen fertilization. The experiment was set up and carried out in a greenhouse, with $7 \mathrm{dm}^{3}$ plastic pots using a oxisoil sampled from the surface layer. A completely randomized experimental design was used with five treatments and six replications. The treatments consisted of five $\mathrm{N}$ levels: $0,40,80,120$ and $160 \mathrm{mg} \mathrm{dm}^{-3}$, using urea as the source. The following were assessed at 180 days: height, stem diameter, leaf, stem, root and total dry matter, $\mathrm{N}$ content in the leaves in the African mahogany leaves. The African mahogany seedlings had high $\mathrm{N}$ demand and responded positively to the $\mathrm{N}$ used and the growth variables was positive with increase in $\mathrm{N}$ level. However, as it presented increasing linear effect, the $\mathrm{N}$ level can not be estimated, that would provide the maximum initial development for this plant species.
\end{abstract}

Keywords: African mahogany, forest fertilization, silviculture

\section{Introduction}

The demand for hardwood has increased greatly and commercial plantations of these species are not being managed to keep up with the rhythm in the market growth (Petrauski et al., 2012). Thus, in order to meet the hardwood demand, it has become necessary to increase commercial plantations of native and exotic species and adopt management practices that ensure efficiency and high yield in the forests plantations (Ciriello et al., 2014).

Among the species exotic to Brazil that are used for commercial ends on the international market there is the African mahogany (Khaya senegalensis A. Juss), which belongs to the family Meliaceae. This specie is naturally from Mauritania and Eastern Senegal to the north of Uganda. It has high commercial value on the international market and is commercialized in several countries in Europe. Also, the African mahogany wood used mainly in for veneers, luxury furniture, interior constructions and shipbuilding (Pinheiro et al., 2011).

The importance of this specie has grown in Brazil because the plant resistance to attack and damage caused by Hypsipyla grandella (Zeller), a pest that severely attacks thenative mahogany plantations (Swietenia macrophylla King). Furthermore, African mahogany adapted well to Brazilian soils also has exceptional silviculture characteristics, as good architecture, with a straight trunk that does not fork, and has few problems with others pests and diseases in all its growth phases (Verzignassi et al., 2009).

The knowledge in nutritional requirements of species is an important tool for obtaining plants with high growth and biomass increase. Nitrogen $(\mathrm{N})$ is outstanding among the nutrients, once it is required in larger quantities by most crops (Marques et al., 2006). In forest species, Goulart et al. (2017) studied Tabebuia serrafolia (Vahl) G. Nichols seedlings 125 days after transplant and verified positive responses in seedling growth in height, stem 
diameter, canopy dry matter and root dry matter up to the level of $100 \mathrm{mg} \mathrm{dm}^{-3}$. Ciriello et al. (2014) reported bigger growth in Calophyllum brasiliense Cambèss plants with the level of $40 \mathrm{mg} \mathrm{dm}^{-3} \mathrm{~N}$ at 10 months of age. However, for exotic hardwood species, such as African mahogany, there are few studies on nitrogen fertilization. Therefore, the authors in this present study aimed to assess the initial growth of African mahogany plants $(K$. senegalensis A. Juss) given nitrogen fertilization.

\section{Methods}

The experiment was set up in a greenhouse in the experimental area at the State University of Goiás, Ipameri Campus (geographic coordinates: $17^{\circ} 43^{\prime} 19^{\prime \prime}$ latitude S and 48 $09^{\prime} 35^{\prime \prime}$ longitude W; $764 \mathrm{~m}$ altitude). The temperature inside the greenhouse ranged from $11^{\circ} \mathrm{C}$ (minimum) to $43{ }^{\circ} \mathrm{C}$ (maximum) and the mean was $27{ }^{\circ} \mathrm{C}$.

The soil used was classified as oxisoil (Embrapa, 2018) collected from the surface layer $(0.20$ to $0.40 \mathrm{~m})$. The soil presented the following attributes: 620,80 and $300 \mathrm{~g} \mathrm{~kg}^{-1}$ sand, silt and clay, respectively, organic matter $=$ $9.0 \mathrm{~g} \mathrm{~kg}^{-1}, \mathrm{CTC}(\mathrm{pH} \mathrm{7.0})=3.36 \mathrm{cmol}_{\mathrm{c}} \mathrm{dm}^{-3}, \mathrm{~V} \%=34.6 ; \mathrm{pH}\left(\mathrm{CaCl}_{2}\right)=5.1, \mathrm{H}+\mathrm{Al}=2.2 \mathrm{cmol}_{\mathrm{c}} \mathrm{dm}^{-3}, \mathrm{P}$ (Mehlich-1) $=1.2 \mathrm{mg} \mathrm{dm}^{-3}, \mathrm{~B}=0.19 \mathrm{mg} \mathrm{dm}^{-3}, \mathrm{Fe}=43.9 \mathrm{mg} \mathrm{dm}^{-3}, \mathrm{~K}=0.04 \mathrm{cmol}_{\mathrm{c}} \mathrm{dm}^{-3}, \mathrm{Ca}=0.8 \mathrm{cmol}_{\mathrm{c}} \mathrm{dm}^{-3}, \mathrm{Mg}$ $=0.3 \mathrm{cmol}_{\mathrm{c}} \mathrm{dm}^{-3}, \mathrm{Cu}=1.9 \mathrm{mg} \mathrm{dm}^{-3}, \mathrm{Zn}=0.2 \mathrm{mg} \mathrm{dm}^{-3}$ and $\mathrm{Mn}=3.4 \mathrm{mg} \mathrm{dm}^{-3}$.

A completely randomized experimental design was used with five treatments and six replications, totalizing 30 experimental units with one plant each (African mahogany). The treatments were five $\mathrm{N}$ levels: $0,40,80,120$ and $160 \mathrm{mg} \mathrm{dm}^{-3}$ and urea (45\%) used as fertilizer source. The levels used were equivalent to $0,80,160,240$ and $320 \mathrm{~kg} \mathrm{ha}^{-1}$. At the day of seedling transplant, the soil contained in the pots was fertilized with micronutrients [Mo $\left.\left(0.1 \mathrm{mg} \mathrm{dm}^{-3}\right), \mathrm{Cu}\left(0.5 \mathrm{mg} \mathrm{dm}^{-3}\right), \mathrm{B}\left(0.5 \mathrm{mg} \mathrm{dm}^{-3}\right), \mathrm{Zn}\left(5 \mathrm{mg} \mathrm{dm}^{-3}\right), \mathrm{Mn}\left(1.5 \mathrm{mg} \mathrm{dm}^{-3}\right)\right]$ and macronutrients $\left[\mathrm{K}\left(80 \mathrm{mg} \mathrm{dm}^{-3}\right)\right.$ and $\left.\mathrm{P}\left(150 \mathrm{mg} \mathrm{dm}{ }^{-3}\right)\right]$. The sources used were: $\mathrm{Na}_{2} \mathrm{MoO}_{4}, \mathrm{CuSO}_{4}, \mathrm{H}_{3} \mathrm{BO}_{3}, \mathrm{ZnSO}_{4}, \mathrm{MnSO}_{4}, \mathrm{KCl}$ and $\mathrm{P}_{2} \mathrm{O}_{5}$, respectively. The nutrients were applied to the soil in each pot and incorporated. Each pot had $7 \mathrm{dm}^{3}$ capacity, with five drainage holes in the base.

After 180 days, the growth variables were assessed by measuring the stem diameter (SD), number of folioles (NF) and plant height $(\mathrm{H})$. The plants were then separated into leaves, stem and roots to determine the dry matter Finally, the parts of the plants were washed with distilled water and placed in a forced air chamber for 72 hours at $70^{\circ} \mathrm{C}$ until constant matter was obtained. After drying, the parts of the plant were weighed on $0.01 \mathrm{~g}$ precision analytic scales to determine the dry matter of the leaves (LDM), stem (SDM) and root (RDM).

To analyze the $\mathrm{N}$ leaf content (NCL), the leaves were ground in a Willey-type stainless steel grinder, with a 20 mesh sieve. The Kjeldahl method (Silva, 2009) was then used to determine the $\mathrm{N}$. The $\mathrm{N}$ amount in the leaves (NAL) was obtained by multiplying the macronutrient content $\left(\mathrm{g} \mathrm{kg}^{-1}\right)$ by the weight of the leaf dry matter $(\mathrm{g})$.

After verifying the assumptions of normality and homogeneity of residual variances of the data, they were submitted to canonic analysis of variables and simple regression analysis to assess the influence of the $\mathrm{N}$ levels on each variable. The statistical analyses were carried out using the R software (R Core Team, 2018) and the candisc package (Friendly \& Fox, 2017).

\section{Results}

There were variation among the treatments for all the variables assessed. A gradual increment of plant height, stem diameter, number of folioles, root dry matter, stem dry matter, leaf dry matter with increasing doses of $\mathrm{N}$ (from 0 to $160 \mathrm{mg} \mathrm{dm}^{-3}$; Figure 1) was observed. However, the $\mathrm{N}$ content in the leaves had the opposite result, and the biggest values were obtained with the lowest $\mathrm{N}$ level $\left(0 \mathrm{mg} \mathrm{dm}^{-3}\right)$.

Considering the lack of overlap between the confidence intervals, it is possible to show three distinct treatment groups: the first group contained the samples referent to the $0 \mathrm{mg} \mathrm{dm}^{-3} \mathrm{~N}$ level, where the plants had the lowest values for the growth variables; the second group was formed by the samples that received the 40 and $80 \mathrm{mg}$ $\mathrm{dm}^{-3} \mathrm{~N}$ levels, where the plants presented intermediate development and the third group was formed by the samples fertilized with 120 and $160 \mathrm{mg} \mathrm{dm}^{-3} \mathrm{~N}$ levels where the plants presented the highest values for the growth variables (Figure 1). 


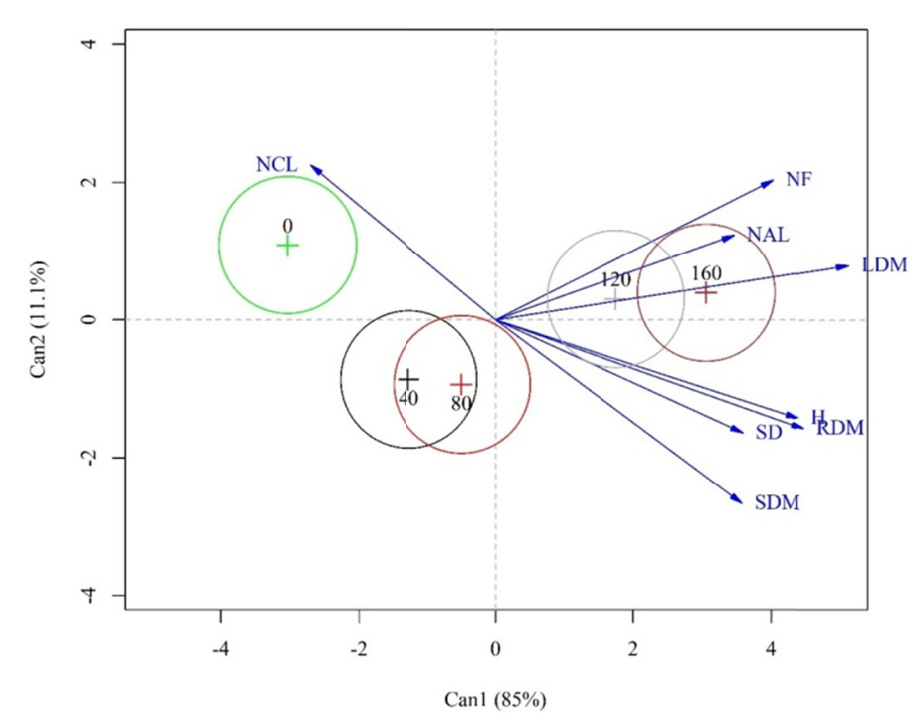

Figure 1. Biplot showing the mean values $(+)$ and the $95 \%$ confidence intervals of the two cannonic variables obtained from plant height $(\mathrm{H})$, stem diameter (SD), number of folioles (NF), root dry matter (RDM), stem dry matter (SDM), leaf dry matter (LDM), $\mathrm{N}$ content in the leaves (NCL) and N amount in the leaves (NAL) of

Khaya senegalensis A. Juss plants fertilized with $\mathrm{N}$ levels: 0, 40, 80, 120 and $160 \mathrm{mg} \mathrm{dm}^{-3}$

The regression functions for height, stem diameter, number of folioles, root dry matter, stem dry matter, leaf dry matter, total dry matter and $\mathrm{N}$ content in the leaves fitted the growing linear model. It was observed that there was an increase in all these variables starting with the application of the $\mathrm{N} 40 \mathrm{mg} \mathrm{dm}^{-3}$ level that increased with the higher applied dose (Figures 2A to $2 \mathrm{H}$ ). However, the $\mathrm{N}$ content in the leaves, decreased with the increasing of dose levels, varying from 19.3 to $13.1 \mathrm{~g} \mathrm{~kg}^{-1}$ (Figure 2H).

The mean height of the African mahogany plants measured that received the maximum $\mathrm{N}$ level $\left(160 \mathrm{mg} \mathrm{dm}^{-3}\right)$ was $53.8 \mathrm{~cm}, 73.7 \%$ higher than the height observed $(31 \mathrm{~cm})$ in the individuals that did not receive nitrogen fertilization $\left(0 \mathrm{mg} \mathrm{dm}^{-3}\right)$ (Figure 2A). For others variables, the observed increases obtained with the highest $\mathrm{N}$ level (160 mg N dm$\left.{ }^{-3}\right)$ in relation to the control treatment $\left(0 \mathrm{mg} \mathrm{N} \mathrm{dm}^{-3}\right)$ were: $30.6 \%$ for SD (Figure 2B); $95.5 \%$ for NF (Figure 2C); 125.1\% in RDM (Figure 2D); 144.2\% in SDM (Figure 2E); 168.6\% in LDM (Figure 2F); and $75.6 \%$ in NAL (Figure 2G). 

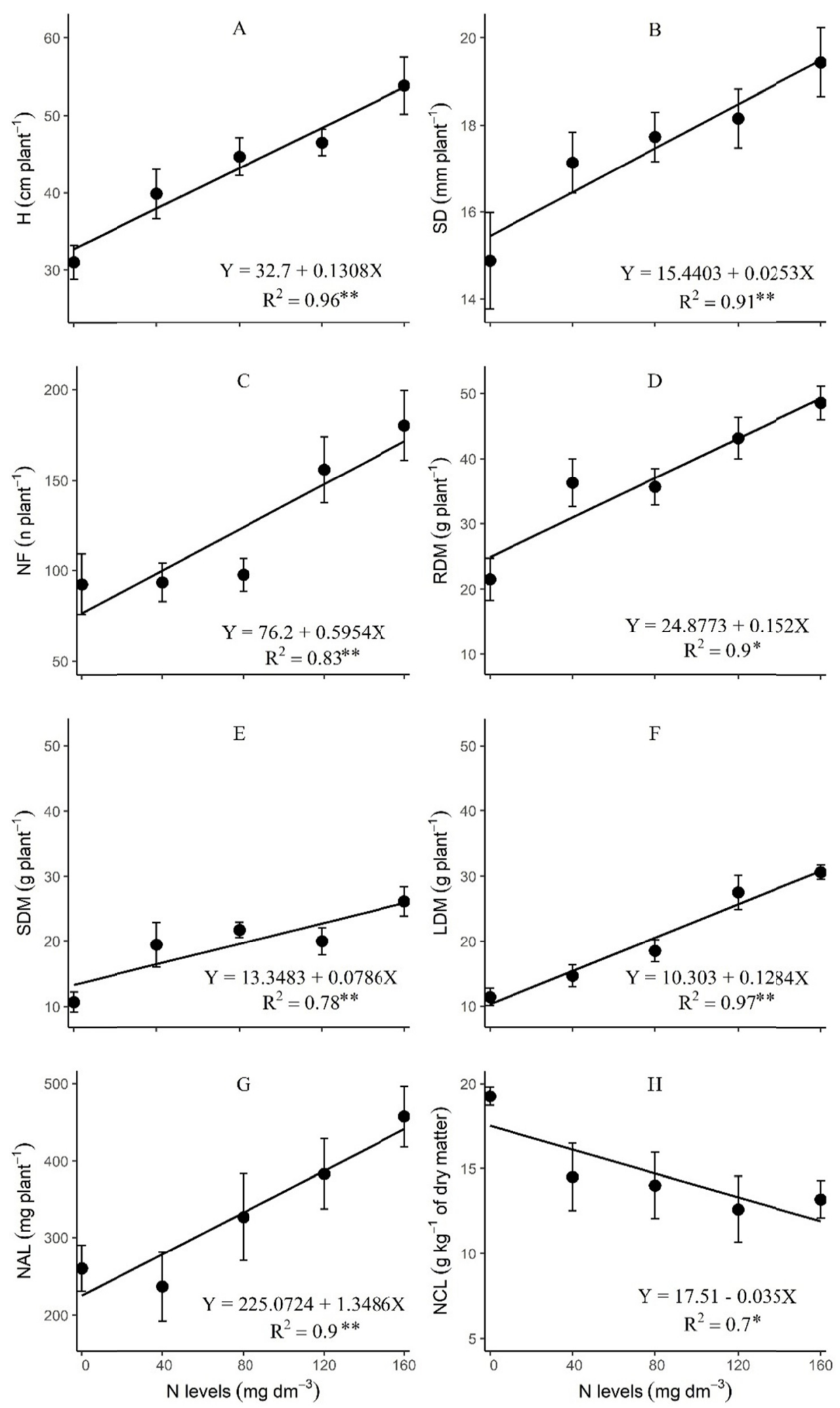

Figure 2. Result of the regression analysis for plant height (H) (A), stem diameter (SD) (B), number of folioles $(\mathrm{NF})(\mathrm{C})$, root dry matter (RDM) (D), stem dry matter (SDM) (E), leaf dry matter (LDM) (F), N content in the leaves (NAL) $(\mathrm{G})$ and $\mathrm{N}$ amount in the leaves (NCL) (H) of Khaya senegalensis A. Juss fertilized with different $\mathrm{N}$ levels. ** Significant at $1 \%$ probability; * significant at $5 \%$ probability. The dots indicate the means and the bars represent the standard error 


\section{Discussion}

The increment of height, diameter, number of folioles, dry matter and $\mathrm{N}$ content in the leaves of African mahogany plants due to higher applied dose of $\mathrm{N}$, that ranged from $30.6 \%$ to $168.6 \%$ in relation to the control, showed the importance of nitrogen fertilization in the initial plant growth of the species. Similar results were obtained by Moro et al. (2014) in Pinus taeda L., but they differed from those obtained by Tucci et al. (2011) in plants of Swietenia macrophylla. It is known that $\mathrm{N}$ is one of the nutrients required in a higher quantity that performs structural actions in aminoacids, proteins, and photosynthetic pigments and especially takes part in the processes of photosynthesis, respiration, cell multiplication and differentiation (Marques et al., 2006).

The biggest increasing in height, $73.7 \%$ observed with the $160 \mathrm{mg} \mathrm{dm}^{-3} \mathrm{~N}$ level application compared to the control, may be justified by the low organic matter content in the soil, $9 \mathrm{~g} \mathrm{~kg}^{-1}$ soil, resulting in low $\mathrm{N}$ supply to the plants. Seedling canopy height correlates well with initial growth in the field, and is technically accepted as a good measure of seedling performance potential (Cruz et al., 2006).

The linear regression, with increment of $30.6 \%$ in the stem diameter compared to the control, also showed a good response to nitrogen by $K$. senegalensis A. Juss in the initial development phase. Stem diameter is one of the most important parameters to estimate survival, after planting of seedlings of different forest species (Afonso et al., 2017). However, as reported in several studies, gains from $\mathrm{N}$ supply are much more modest or in some cases are absent in initial seedling growth. The absence of response to nitrogen fertilization in plants of Swietenia macrophylla King was observed by Tucci et al. (2009), and in Peltophorum dubium (Spreng.) Taub. by Cruz et al., (2011). Cruz et al. (2006) found an increase of up to $8 \%$ in the stem diameter due to nitrogen fertilization in Samanea inopinata (Harms) Ducke.

The number of leaves increased $95.5 \%$ compared to the control, while for the MSF the increasing was $168.6 \%$. This reflected in the gains on SDM and RDM of $144.2 \%$ and $125.1 \%$, respectively. Similar results were reported by Freiberger et al., (2013), but in Cedrela fissilis Vell., Cruz et al. (2006) found highest plant dry matter indicating in this way better seedling quality.

The nitrogen content found in the K. senegalensis A. Juss leaves decreased $31.4 \%$ with the $\mathrm{N}$ dose increased. This result is directly related to the effect of dilution, since there was increase of dry matter production and $\mathrm{N}$ accumulation (Fernandes et al., 2008). The plants that receveid increasing levels $\left(40,80,120\right.$ and $\left.160 \mathrm{mg} \mathrm{dm}^{-3}\right)$ showed best results in all the variables analyzed when compared to the plants given the level $0 \mathrm{mg} \mathrm{dm}^{-3} \mathrm{~N}$ level. Because that, they had lower contents of $\mathrm{N}$ in the leaves. The values found are considered adequate for plant growth and development, in which according to Epstein and Bloom (2006), are approximately $15 \mathrm{~g} \mathrm{~kg}^{-1}$.

The linear increment obtained in the present study was due to the fact that large quantities of $\mathrm{N}$ are required by the plants, especially in the initial development phase (Malavolta et al., 1997). However, as the plant develops nitrogen management continues to require attention, since plants usually respond well to nitrogen fertilization, excess $\mathrm{N}$ is harmful and the quantities supplied to the plant should be well adjusted in relation to the quantity of the other nutrients. In this sense, Ciriello et al. (2014), worked with guanandi (Calophyllum brasiliense Cambèss) seedlings, in which observed positive responses to increasing $\mathrm{N}$ levels, but at the maximum level $\left(160 \mathrm{mg} \mathrm{dm}^{-3}\right)$ there was a negative effect on diameter and root dry matter mass. Corcioli et al. (2016) studied another African mahogany species (K. ivorensis A. Chev.), and also showed the importance of $\mathrm{N}$ in the initial seedling growth, since the development of plants submitted to $\mathrm{N}$ omission via fertilization was negatively affected.

The responses to the nitrogen levels used in the present study showed the importance of this macronutrient on the initial biomass production in African mahogany plants however, once it is presented an increasing linear effect, the $\mathrm{N}$ level can not be estimated which would provide the maximum initial development to plants of this species. However, our results showed that African mahogany (K. senegalensis A. Juss) has high nitrogen requirement in the initial development phase.

\section{Conclusions}

The better performance of African mahogany seedlings was obtained with the dose of $160 \mathrm{mg} \mathrm{dm}^{-3} \mathrm{~N}$.

This level of application can be used as fertilization for the production of species in soils with chemical and physical characteristics similar to those used in the present study.

\section{References}

Afonso, M. V., Martinazzo, E. G., Aumonde, T. Z., \& Villela, F. A. (2017). Physiological parameters of Albizia niopoides seedlings produced in different substrate compositions. Ciência Florestal, 27, 1395-1402. https://doi.org/10.5902/1980509830221 
Ciriello, V., Guerrini, I. A., \& Backes, C. (2014). Doses de nitrogênio no crescimento inicial e nutrição de plantas de guanandi. Cerne, 20, 653-660. https://doi.org/10.1590/01047760201420041445

Corcioli, G., Borges, J. D., \& Jesus, R. P. (2016). Deficiência de macro e micronutrientes em mudas maduras de Khaya ivorensis estudadas em viveiro. Cerne, 22, 121-128. https://doi.org/10.1590/010477602016220 12085

Cruz, C. A. F., Paiva, H. N., Cunha, A. C. M. C. M., \& Neves, J. C. L. (2011). Macronutrients in production of Peltophorum dubium (Spreng.) Taub. seedlings in red yellow ultisol of the zona da mata, MG Region. Ciência Florestal, 21, 445-457. https://doi.org/10.5902/198050983802

Cruz, C. A. F., Paiva, H. N., \& Guerrero, C. R. A. (2006). Efeito da adubação nitrogenada na produção de mudas de sete-cascas (Samanea inopinata (Harms) Ducke). Revista Árvore, 30, 537-546. https://doi.org/10.1590/ S0100-67622006000400006

Embrapa. (2018). Sistema brasileiro de classificação de solos (5rd ed.). Rio de Janeiro: Embrapa Solos.

Epstein, E., \& Bloom, A. (2004). Nutrição mineral de plantas: Princípios e perspectivas (2nd ed.). Londrina: Planta.

Fernandes, L. A., Alves, D. S., Silva, L. F., Silva, N. C. A., Martins, E. R., Sampaio, R. A., \& Costa, C. A. (2008). Níveis de nitrogênio, fósforo e potássio para a produção de mudas de fava d'anta (Dimorphandra mollis Benth). Revista Brasileira Plantas Medicinais, 10, 94-99.

Freiberger, M. B., Guerrini, I. A., Galetti, G., Fernandes, D. M., \& Corrêa, J. C. (2013). Crescimento inicial e nutrição de cedro (Cedrela fissilis Vell.) em função de doses de nitrogênio. Revista Árvore, 37, $385-392$. https://doi.org/10.1590/S0100-67622013000300001

Friendly, M., \& Fox, J. (2017). Candisc: Visualizing Generalized Canonical Discriminant and Canonical Correlation Analysis. $R$ Package Version 0.8-0. Retrieved from https://CRAN.R-project.org/ package $=$ candisc

Goulart, L. M. L., Paiva, H. N., Leite, H. G., Xavier, A., \& Duarte, M. L. (2017). Produção de mudas de ipê-amarelo (Tabebuia serratifolia) em resposta a fertilização nitrogenada. Floresta e Ambiente, $24,1-9$. https://doi.org/10.1590/2179-8087.137315

Malavolta, E., Vitti, G. C., Oliveira, S. A., \& Malavolta, E. (1997). Avaliação do estado nutricional das plantas: Princípios e aplicações (2nd ed.). Piracicaba: Potafos.

Marques, V. B., Paiva, H. N., Gomes, J. M., \& Neves, J. C. L. (2006). Efeitos de fontes e doses de nitrogênio no crescimento de mudas de sabiá (Mimosa caesalpiniaefolia Benth.). Scientia Forestalis, 71, 77-85.

Moro, L., Gatiboni, L. C., Simonete, M. A., Cassol, P. C., \& Chaves, D. M. (2014). Resposta de Pinus taeda com diferentes idades à adubação NPK no planalto Sul Catarinense. Revista Brasileira de Ciência do Solo, 38, 1181-1189. https://doi.org/10.1590/S0100-06832014000400014

Petrauski, S. M. F. C., Marques, G. M., Silva, M. L., Cordeiro, S. A., \& Soares, N. S. (2012). Competitividade do Brasil no mercado internacional de madeira serrada. Cerne, 18, 99-104. https://doi.org/10.1590/S0104-776 02012000100012

Pinheiro, A. L., Couto, L., Pinheiro, D. T., \& Brunetta, J. M. F. C. (2011). Ecologia, silvicultura e tecnologia de utilização dos mognos-africanos (Khaya spp.). Viçosa: Sociedade Brasileira de Agrossilvicultura.

R Core Team. (2018). R: A Language and Environment for Statistical Computing. Vienna, Austria, R Foundation for Statistical Computing. Retrieved from https://www.R-project.org

Silva, F. C. (2009). Manual de Análises Químicas de Solo, Plantas e Fertilizantes (2nd ed.). Brasília: Embrapa Informação Tecnológica.

Tucci, C. A. F., Lima, H. N., \& Lessa, J. F. (2009). Adubação nitrogenada na produção de mudas de mogno (Swietenia macrophylla King). Acta Amazônica, 39, 289-294. https://doi.org/10.1590/S0044-59672009000 200007

Tucci, C. A. F., Santos, J. Z. L., Silva-Júnior, C. H., Souza, P. A., Batista, I. M. P., \& Venturin, N. (2011). Desenvolvimento de mudas de mogno Swietenia macrophylla em resposta a nitrogênio, fósforo e potássio. Revista Floresta, 41, 471-490. https://doi.org/10.5380/rf.v41i3.24039

Verzignassi, J. R., Poltronieri, L. S., \& Benchimol, R. L. (2009). Mancha-alvo em mogno-africano no Brasil. Summa Phytopathologica, 35, 70-71. https://doi.org/10.1590/S0100-54052009000100015 


\section{Copyrights}

Copyright for this article is retained by the author(s), with first publication rights granted to the journal.

This is an open-access article distributed under the terms and conditions of the Creative Commons Attribution license (http://creativecommons.org/licenses/by/4.0/). 